\title{
National quality register of congenital heart diseases - Can we trust the data?
}

Amanda Bodell', Gudrun Björkhem ${ }^{2}$, Ulf Thilén ${ }^{3}$ and Estelle Naumburg ${ }^{1,4^{*}}$ (i)

\begin{abstract}
Background: The SWEDish registry of CONgenital heart disease is a Swedish national quality register for collecting data on pediatric and adult (GUCH) patients with congenital heart diseases that aims to improve medical practice and research. The aim of this study was to validate data in the register using data in medical records.

Methods: This cross-sectional observational study compared specific variables from SWEDCON with data retrieved from medical records for 182 pediatric and 186 adult patients who were randomly selected from four different hospitals.

Results: The absolute concordance for date of visit, diagnosis, information on surgery and catheter intervention was $71-98 \%$ between SWEDCON and medical journals. The specificity for cardiac examinations and specific medical therapy was $71-100 \%$. The concordance for information for transition from pediatric care to GUCH or finishing regular check-ups was $92 \%$.

Conclusion: The overall concordance between data in SWEDCON-pediatric as well as SWEDCON-GUCH with data in medical records was good, and data from SWEDCON is reliable to use for medical improvements and for research purposes.
\end{abstract}

Keywords: Congenital heart defects, National Quality Register, Validation

\section{Background}

Every year in Sweden, 800-1000 children are born with a congenital heart defect. Survival rates have improved and the population of adults with congenital heart defects now exceeds.

40,000 in Sweden [1, 2]. Government-administered registers cover a high proportion of the population in Sweden, but often lack detailed information on diseasespecific data, patient-reported outcome measures such as quality of life (QoL) or aspects of management. The SWEDish registry of CONgenital heart disease [3] is a Swedish national quality register for collecting data on patients with congenital heart diseases. The adult register was created in the early 1990s and, by 2009 , a pediatric and a surgical section had been merged with the register, with data also being imported from other hospital-based registers. The register now has four parts: fetal heart diagnosis,

\footnotetext{
* Correspondence: estelle.naumburg@umu.se

${ }^{1}$ Department of Clinical Science, Pediatrics, Umeå University, Umeå, Sweden

${ }^{4}$ Unit of Research, Education and Development, Östersund Hospital, 83183

Östersund, Sweden

Full list of author information is available at the end of the article
}

pediatric cardiology, Grown Up Congenital Heart disease $(\mathrm{GUCH})$ and congenital heart surgery. These have a common basis, with information on each patient, including personal data, diagnosis, operations and catheter interventions. Information on mortality is either derived from user input - the basis for our analysis - or from monthly updates to official statistics, which are used in analytical reports from the register. The SWEDCON register is longitudinal, making it possible to follow patients with congenital heart disease throughout their entire lives, as data from the different parts of the register are combined.

Nationwide, 31 pediatric units register individuals less than 19 years old in SWEDCON-pediatric. Patients older than 16 years are registered in SWEDCON/GUCH if they have had at least one evaluation at one of the seven GUCH centers or the 15 (out of 18) county hospitals that are affiliated to SWEDCON-GUCH. SWEDCON has an overall coverage rate of $84 \%$ of all hospitals in the country [4]. The aim of the register is to improve medical practice, both in the long and the short-term, and to be 
used for research. An increasing number of studies are based on SWEDCON, although a nationwide validation has not yet been done.

The aim of this validation study was to assess data registered in SWEDCON-pediatric and SWEDCON-GUCH against the data registered in the patients' medical records.

\section{Methods}

\section{Study design and study sample}

This cross-sectional observational study, performed in the second half of 2016, compared specific variables from SWEDCON with data in medical records. Two larger centers and two county hospitals in different parts of Sweden were included in the study. The hospitals were representative of all hospitals treating patients with congenital heart defects.

Over 200 pediatric and $200 \mathrm{GUCH}$ patients from these hospitals were randomly selected by the register-holders. Inclusion was restricted to certain main cardiac diagnoses in order to improve the study's specificity (Table 1 and 2) and to patients born in 2015 or earlier.

Data was manually retrieved by one of the authors (AB) from medical records and compared with data registered in SWEDCON in a standardized manner (Table 1). AB, a medical student, was specially trained in the nomenclature of congenital cardiology and supervised by a pediatric cardiologist (EN).

\section{Information of analysis of specific variables}

\section{Outpatient visits}

The last two registered outpatient visits at a GUCH or pediatric clinic in 2009 or after were recorded. Concordance with the date of visit was assessed as true within 7 days between the date of visit and date of registration. Examinations that are seldom performed during an outpatient clinical visit (such as angiography or coronary angiography, heart catheterization, isotope, chest radiograph, MRI, electrophysiology, CT, fetal echocardiography and 24-h blood pressure), were considered concordant with the date of an outpatient clinical visit if the examination took place within 3 months of the outpatient clinical visit, as this is a normal interval from referral to this type of examination.

Visits to a sonographer were registered as a doctor's visit in the protocol when echocardiography was evaluated by a pediatric cardiologist. When a consultant from a GUCH center examined a patient at a smaller hospital, the visit was recorded as having been performed at the smaller hospital if this hospital was included in the study. If the smaller hospital was not included in the study, we had no access to medical records and the patient was therefore excluded from analysis (Fig. 1). Further, special analysis was preformed to check whether the last visit in SWEDCON was
Table 1 Demographics

\begin{tabular}{|c|c|c|c|}
\hline & Male $=\mathrm{N}$ & Female $=\mathrm{N}$ & Total $=\mathrm{N}$ \\
\hline \multicolumn{4}{|l|}{ Children total } \\
\hline Type of heart defect & 107 (59\%) & 75 (41\%) & 182 \\
\hline o Fontan & 8 & 4 & 12 \\
\hline$\circ$ VSD & 27 & 17 & 44 \\
\hline$\circ$ ASD & 33 & 40 & 73 \\
\hline ○ Fallot & 18 & 8 & 26 \\
\hline$\circ$ Aortic stenosis & 20 & 6 & 27 \\
\hline \multicolumn{4}{|l|}{ Hospitals } \\
\hline $\begin{array}{l}\text { ○ Östersund hospital } \\
\text { (minor hospital) }\end{array}$ & 9 & 9 & 18 \\
\hline $\begin{array}{l}\text { o Kalmar hospital } \\
\text { (minor hospital) }\end{array}$ & 21 & 13 & 34 \\
\hline $\begin{array}{l}\text { o Stockholm hospital } \\
\text { (major center) }\end{array}$ & 41 & 32 & 73 \\
\hline ○ Lund hospital (major center) & 36 & 21 & 57 \\
\hline \multicolumn{4}{|l|}{ Information on visits } \\
\hline $\begin{array}{l}\text { Information on last visit } \\
\text { (SWEDCON) }\end{array}$ & 107 & 75 & 182 \\
\hline $\begin{array}{l}\text { Information on visit before last } \\
\text { visit (SWEDCON) }\end{array}$ & 75 & 51 & 126 \\
\hline GUCH total & $90(48 \%)$ & $96(52 \%)$ & 186 \\
\hline \multicolumn{4}{|l|}{ Type of heart defect } \\
\hline - Fontan & 8 & 4 & 12 \\
\hline$\circ V S D$ & 17 & 26 & 43 \\
\hline$\circ$ ASD & 30 & 51 & 81 \\
\hline$\circ$ Fallot & 16 & 7 & 23 \\
\hline$\circ$ Aortic stenosis & 19 & 8 & 27 \\
\hline \multicolumn{4}{|l|}{ Hospitals } \\
\hline $\begin{array}{l}\text { ○ Östersund hospital } \\
\text { (minor hospital) }\end{array}$ & 2 & 3 & 5 \\
\hline $\begin{array}{l}\text { o Kalmar hospital } \\
\text { (minor hospital) }\end{array}$ & 12 & 17 & 29 \\
\hline $\begin{array}{l}\text { o Stockholm hospital } \\
\text { (major center) }\end{array}$ & 45 & 46 & 91 \\
\hline ○ Lund hospital (major center) & 31 & 30 & 61 \\
\hline \multicolumn{4}{|l|}{ Information on visits } \\
\hline $\begin{array}{l}\text { Information on last visit } \\
\text { (SWEDCON) }\end{array}$ & 73 & 50 & 183 \\
\hline $\begin{array}{l}\text { Information on visit before last } \\
\text { visit (SWEDCON) }\end{array}$ & 56 & 61 & 117 \\
\hline
\end{tabular}

VSD ventricular septal defect, $A S D$ atrial septal defect

concordant with the visit before last one in the medical record, and vice versa.

Only major cardiac centers register stays in hospital, so inpatient stays were therefore not recorded in this study.

The transition of care from pediatric to $\mathrm{GUCH}$, as well as finishing regular check-ups, is marked specifically in 
Table 2 Retrieval of information in SWEDCON in medical journals

\begin{tabular}{l}
\hline Variable \\
\hline Main diagnosis from SWEDCON (also inclusion criteria): \\
- Tetralogy of Fallot (ICD-10: Q21.3, EPCC: 01.01.01, 01.01.06, 01.01.25) \\
- Fontan circulation (ICD-10: Q20.8-9, Q23.4, EPCC: 01.01.22, 07.08.41, \\
07.08.42, 07.02.00, 07.07.00, 01.01.09) \\
- Ventricular septal defect (VSD) (ICD-10: Q21.0, EPCC: 07.10.00-07.10.05, \\
07.11.01, 07.12.00-07.12.01) \\
- Atrial septal defect (ASD/PFO) (ICD-10: Q21.1, EPCC: 05.04.01, 05.04.02, \\
05.03.01) \\
- Aortic stenosis (ICD-10: Q23.0, EPCC: 09.15.92, 09.15.00, 09.15.01, 09.15.13)
\end{tabular}

Cardiac diagnosis and genetic disorders (main and total) registered at the last two visits in medical record and in SWEDCON

\section{Date of last two visits}

Medical therapy:

- Information on medication; yes or no.

- Type of medical therapy (independent of date):

o Children: heart failure treatment, antiarrhythmic treatment, antithrombotic treatment, treatment for systemic hypertension, treatment for pulmonary hypertension, immunomodulatory - GUCH: pacemaker, Sotalol, class I antiarrhythmic agent, Amiodarone, other antiarrhythmic, beta blocker, calcium channel blocker, digitalis, diuretics, nitroglycerin, ACEl (angiotensin-converting-enzyme inhibitor), ARB (angiotensin II receptor blocker), ASA (acetylsalicylic acid), thrombocyte inhibitor other than ASA, Waran, NOAC (NonVitamin K Antagonist Oral Anticoagulants), other agent against systemic hypertension, endothelin receptor antagonist, Sildenafil, prostacyclin analogue, other agent against pulmonary hypertension, agent against hyperlipidaemia, oxygen therapy

\section{Examinations}

- Children: date and examinations performed at the last two out clinic visits; ECG (electrocardiography), ECO (echocardiography), TEE (transesophageal echocardiography), chest radiograph, exercise ECG (electrocardiography), 24-h ECG, control of PM (pacemaker)/ICD (implantable cardioverter defibrillator), Isotope, MRI (Magnetic Resonance Imaging),

CT (Computed Tomography)

- GUCH: date for the last examination, ECG, exercise ECG,

echocardiography, Angiography or coronary angiography, heart catheterization, isotope, chest radiograph, MRI, electrophysiology, CT, fetal echocardiography, 24-h-bloodpressure

\section{Surgeries and catheter interventions and diagnoses}

Information on ending of follow-ups, information on transition to GUCH or deceased (pediatric).

ICD-10 = WHO. World Health Organization. International Statistical Classifications of Diseases and Related Health Problems 10th Revision. http://www.who.int/classifications/icd/en/

EPCC $=$ Coding Committee of the Association for European Paediatric $C$. The European Paediatric Cardiac Code: the first revision. Cardiol Young. 2002;12 Suppl 2:1-211

GUCH = Grown Up Congenital Heart disease

SWEDCON, and this was measured as concordant when there was a transition stated in the medical record. Finishing regular check-ups may be marked in SWEDCON when no more visits are needed, such as in cases that are spontaneously closed ASD.

\section{Diagnosis}

The main cardiac diagnoses in SWEDCON were compared to main cardiac diagnoses in medical records. Cardiac diagnoses in SWEDCON are registered according

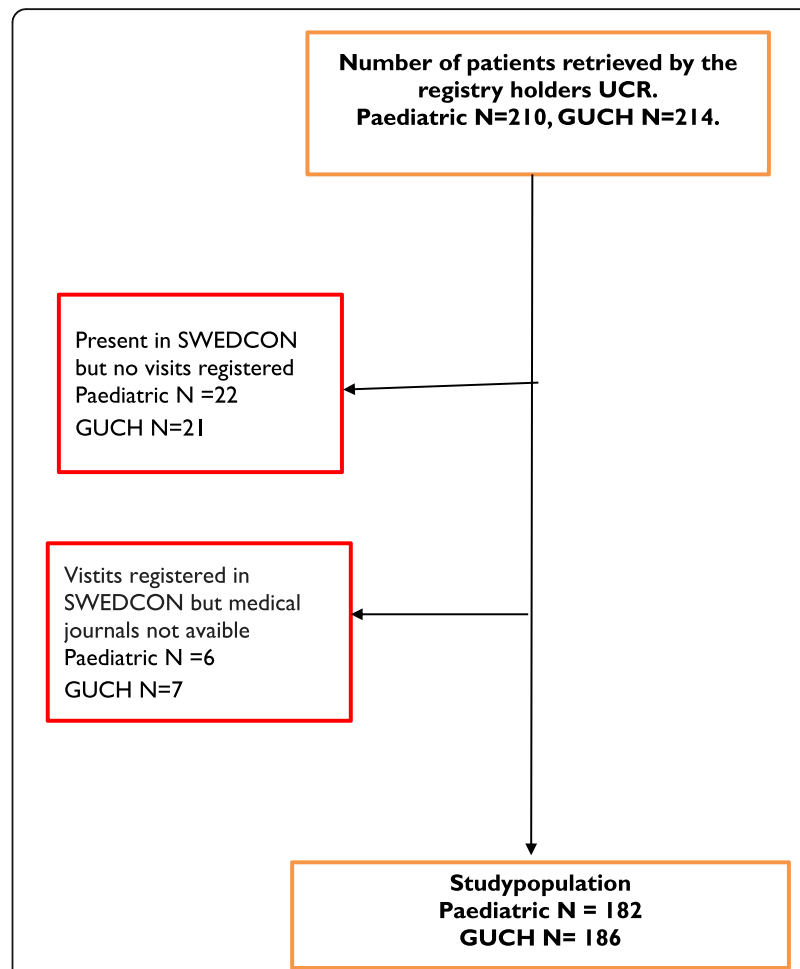

Fig. 1 Retrieval of study population

to the European pediatric cardiac coding [5] and the WHO ICD-10 codes [6]. Similar diagnoses within the same ICD 10-group were recorded as concordance of diagnosis. Classification of surgical and catheter inventions were recorded using the "Swedish classification of care measures" (KVÅ) [7]. In the absence of KVA classification in the medical record, the full name of the surgical or catheter intervention was translated to the KVÅ classification.

\section{Statistical analysis}

Data retrieved from SWEDCON was compared to data registered in medical records. The number and proportion of data corresponding to each data source were calculated. The degree of agreement was estimated using the percentage of agreement and Cohen's kappa when appropriate. Sensitivity and specificity were analyzed using data from the medical record to be the true value, and a confidence interval of $95 \%$ was used.

\section{Results}

\section{Study population}

In total, 210 patients were randomly retrieved by Uppsala Clinical Research Centre (UCR), the register's technical platform, from SWEDCON-pediatric and 214 patients from SWEDCON-GUCH. From these, 28 pediatric patients and $28 \mathrm{GUCH}$ patients were excluded from the study because either no outpatient visits had been recorded 
in SWEDCON or the medical records were not available (Fig. 1).

\section{Concordance of information between SWEDCON and medical records}

The pediatric study population consisted of 182 patients (Table 1) and most patients had more than one visit (85\%). The overall concordance between SWEDCON-pediatric and medical records was good. The absolute concordance for date of visit was $71 \%$, for cardiac diagnosis $74 \%$ and for cardiac therapy $98 \%$. The concordance for transition from pediatric care to GUCH or finishing regular check-ups was 92\%, with a Cohen's kappa of 0.89 (Table 3).

The concordance between SWEDCON and medical records for performed examinations related to the last medical outpatient visit was $87-100 \%$, with a specificity of $100 \%$ for most data (Table 4 ).

The GUCH study population consisted of 186 patients (Table 1). The majority of patients had more than one visit (80\%). Date of visit was concordant to $85 \%$. The degree of concordance between SWEDCON and medical records on diagnosis was $79-80 \%$ (Table 3). The concordance between SWEDCON and medical records for examinations was between 72 and 99\% (Table 4).

Medical treatment was grouped differently in SWEDCON-pediatric and SWEDCON-GUCH. The concordance between data regarding different types of medical treatment in SWEDCON and medical records was $86-100 \%$ with a specificity of $86-100 \%$ and a sensitivity of $50-100 \%$ (Table 5). Medical cardiac therapy was only analyzed for patients on medical therapy.

There were no deaths in the GUCH population. Two patients in the pediatric study population were deceased according to medical records, but only one of these was registered as deceased in SWEDCON.

\section{Discussion}

Overall, the concordance for data in SWEDCON registry compared to data in medical records was good. Specificity ranged from 71 to $100 \%$, which implies that information in the SWEDCON register is accurate for the majority of the data. Sensitivity ranges from 33 to $100 \%$, where almost half the variables (16 out of 34 variables) have a sensitivity above $80 \%$.

Quality register data are used for health quality improvements and research. Validation as well as presentation have been published and good inter-reliability has been found for many Swedish quality registers [8-10]. The overall concordance of data between SWEDCON and medical records, along with a coverage rate for SWEDCON of $84 \%$, supports the idea of using data from SWEDCON for health improvements and research.

Participation in SWEDCON is voluntary, for both patients and medical staff. The overall experience from the research group is that few patients and no participating medical staff have refused to register in SWEDCON. Data is reported in SWEDCON by physicians, registered nurses or specially trained secretaries at the time of the patient visit, or shortly thereafter. Older data have been imported to SWEDCON from local registers in Lund and Stockholm at the start of the pediatric part of SWEDCON. Excellent concordance between information in medical records and SWEDCON was seen for examinations and medical treatment, while concordance was less robust on specific dates of visits, exact diagnosis, surgical and catheter interventions. The reason for this is not known, we speculate that

Table 3 Concordance between SWEDCON and medical records. Visits and diagnosis

\begin{tabular}{|c|c|c|c|c|}
\hline & $\begin{array}{l}\text { Information in } \\
\text { SWEDCON N (\%) }\end{array}$ & $\begin{array}{l}\text { Information in } \\
\text { medical record N (\%) }\end{array}$ & $\begin{array}{l}\text { Data in both SWEDCON } \\
\text { and medical records N (\%) }\end{array}$ & Concordance (\%) \\
\hline \multicolumn{5}{|l|}{ SWEDCON/children } \\
\hline Date of visit & $308(92 \%)$ & 331 (99\%) & $303(90 \%)$ & $71 \%$ \\
\hline Main cardiac diagnosis & $181(99 \%)$ & $282(85 \%)$ & $280(85 \%)$ & $74 \%$ \\
\hline All cardiac diagnosis & $181(99 \%)$ & $173(95 \%)$ & $172(95 \%)$ & $74 \%$ \\
\hline Surgery (diagnosis) & $50(94 \%)$ & $53(100 \%)$ & $50(94 \%)$ & $77 \%$ \\
\hline Catheter interventions (diagnosis) & $17(94 \%)$ & $17(94 \%)$ & $16(89 \%)$ & $71 \%$ \\
\hline Cardiac medical therapy & 169 (93\%) & $175(96 \%)$ & $162(89 \%)$ & $98 \%$ \\
\hline \multirow[t]{2}{*}{ Information on transition to GUCH or end of check-ups } & Yes $=59$ & Yes $=62$ & 182 & $92 \%$ \\
\hline & $\mathrm{No}=123$ & $\mathrm{No}=120$ & & \\
\hline \multicolumn{5}{|l|}{ SWEDCON/GUCH } \\
\hline Date of visit & $300(90 \%)$ & 331 (99\%) & 297 (89\%) & $85 \%$ \\
\hline Main cardiac diagnosis & $186(100 \%)$ & 293 (89\%) & 293 (89\%) & $80 \%$ \\
\hline All cardiac diagnosis & $186(100 \%)$ & 180 (97\%) & 180 (97\%) & $79 \%$ \\
\hline Catheter interventions (diagnosis) & 47 (98\%) & $46(96 \%)$ & 45 (94\%) & $90 \%$ \\
\hline
\end{tabular}


Table 4 Information on examinations and medical therapy

\begin{tabular}{|c|c|c|c|c|c|c|c|c|}
\hline \multicolumn{2}{|l|}{ Variable } & \multicolumn{2}{|c|}{ Information in SWEDCON } & \multicolumn{2}{|c|}{ Information in medical records } & \multirow[t]{2}{*}{ Concordance (\%) } & \multirow[t]{2}{*}{ Specificity } & \multirow[t]{2}{*}{ Sensitivity } \\
\hline & & $\begin{array}{l}\text { Examination } \\
\text { performed }\end{array}$ & $\begin{array}{l}\text { Examination } \\
\text { not performed }\end{array}$ & $\begin{array}{l}\text { Examination } \\
\text { performed }\end{array}$ & $\begin{array}{l}\text { Examination } \\
\text { not performed }\end{array}$ & & & \\
\hline \multirow{10}{*}{$\begin{array}{l}\text { Pediatric information on } \\
\text { performed examinations }\end{array}$} & $\mathrm{ECG}^{\mathrm{a}}$ & 205 & 37 & 228 & 14 & $87 \%$ & $71 \%$ & $88 \%$ \\
\hline & $\mathrm{ECHO}^{\mathrm{b}}$ & 239 & 3 & 242 & 0 & $99 \%$ & - & $99 \%$ \\
\hline & $\mathrm{TEE}^{\mathrm{C}}$ & 0 & 242 & 0 & 242 & $100 \%$ & $100 \%$ & - \\
\hline & Chest $x$-ray & 8 & 234 & 8 & 234 & $98 \%$ & $99 \%$ & $63 \%$ \\
\hline & Exercise test & 16 & 226 & 14 & 228 & $97 \%$ & $98 \%$ & $79 \%$ \\
\hline & $24 \mathrm{~h} \mathrm{ECG}^{\mathrm{a}}$ & 13 & 229 & 14 & 228 & $97 \%$ & $99 \%$ & $71 \%$ \\
\hline & PM/ICD-control & 1 & 241 & 0 & 242 & $100 \%$ & $100 \%$ & - \\
\hline & Isotope & 2 & 240 & 0 & 242 & $99 \%$ & $99 \%$ & - \\
\hline & $\mathrm{MRI}^{\mathrm{d}}$ & 4 & 238 & 3 & 239 & $99 \%$ & $99 \%$ & $67 \%$ \\
\hline & $C T^{e}$ & 0 & 242 & 1 & 241 & $100 \%$ & $100 \%$ & $0 \%$ \\
\hline \multirow{12}{*}{$\begin{array}{l}\text { GUCH information on } \\
\text { performed examinations }\end{array}$} & $\mathrm{ECG}^{\mathrm{a}}$ & 178 & 8 & 186 & 0 & $79 \%$ & & \\
\hline & Exercise test & 61 & 125 & 80 & 106 & $72 \%$ & & \\
\hline & $\mathrm{ECHO}^{\mathrm{b}}$ & 179 & 7 & 185 & 1 & $81 \%$ & & \\
\hline & $\begin{array}{l}\text { Angiography or } \\
\text { coronary angiography }\end{array}$ & 12 & 174 & 17 & 169 & $88 \%$ & & \\
\hline & Heart catheterization & 14 & 172 & 40 & 146 & $82 \%$ & & \\
\hline & Isotope & 6 & 180 & 7 & 179 & $95 \%$ & & \\
\hline & Chest x-ray & 25 & 161 & 52 & 134 & $73 \%$ & & \\
\hline & $M R l^{d}$ & 25 & 161 & 42 & 144 & $87 \%$ & & \\
\hline & Electrophysiology & 1 & 185 & 1 & 185 & $99 \%$ & & \\
\hline & $\mathrm{CT}^{\mathrm{e}}$ & 6 & 180 & 27 & 159 & $86 \%$ & & \\
\hline & $\begin{array}{l}\text { Fetal } \\
\text { echocardiography }\end{array}$ & 0 & 186 & 1 & 185 & $99 \%$ & & \\
\hline & $\begin{array}{l}\text { 24-h blood pressure } \\
\text { examination }\end{array}$ & 2 & 184 & 5 & 181 & $98 \%$ & & \\
\hline
\end{tabular}

${ }^{\mathrm{a}} E C G$ electrocardiogram, ${ }^{\mathrm{b}} E C H O$ echocardiography, ${ }^{\mathrm{c}} T E E$ transesophageal echocardiography, ${ }^{\mathrm{d}} \mathrm{MRI}$ magnetic resonance imaging, ${ }^{\mathrm{e}} \mathrm{C} T$ computed tomography

as the manually recording of diagnosis (main and secondary diagnosis) is made differently in medical records and SWEDCON, the main diagnosis appears be nonconcordance when comparing, while it is the ranking of diagnoses that differs. Further, our study did not include old data, as the inclusion criteria were visits in 2009 or after that were registered in SWEDCON, which may have influenced the inferior results in our study for information on diagnosis and interventions (surgery and catheter) compared to data in medical records. A small validity control of 132 patients in SWEDCON-GUCH found a concordance of $95 \%$ for main diagnosis, surgical KVÅ code and date of last surgery [3]. That study did not have limitations on the date of registration, birth year and hospital, and thus we believe the concordance between SWEDCON and medical records may be better than we were able to prove in our study.

ICD-10 codes and KVÅ codes are used in medical records; as European pediatric cardiac coding (EPCC) is used to register data in SWEDCON, the EPCC codes had to be manually translated to diagnostic codes in the ICD-10 and KVA systems for the comparison. This may have introduced a misclassification in our study. However, we used words which described the surgery and intervention, not only the code, in our registration and so we believe the risk of misclassification was reduced. Agreement on diagnostic tool and awareness of the inconsistencies between the EPCC and the ICD-10 and KVA codes is crucial when studying SWEDCON data and comparing it with medical records or other national registries $[11,12]$.

The four parts of SWEDCON make it possible to follow a patient throughout their entire life. Follow-up studies have been performed on adults with aortic valve, coarctation and Mustard/Senning correction, and research has been performed on physical activity and muscle function in adults with congenital heart disease, as well as closure of atrial septal defect by device in the elderly and studies on incidence of endocarditis [13-17]. The SWEDCON registry has been the basis for studies on the transition 
Table 5 Information on medical therapy

\begin{tabular}{|c|c|c|c|c|c|c|c|c|}
\hline \multirow[t]{2}{*}{ Variable } & & \multicolumn{2}{|c|}{ Information in Swedcon } & \multicolumn{2}{|c|}{ Information in medical records } & \multirow[t]{2}{*}{ Concordance (\%) } & \multirow[t]{2}{*}{ Specificity } & \multirow[t]{2}{*}{ Sensitivity } \\
\hline & & $\begin{array}{l}\text { Number of } \\
\text { patients with } \\
\text { treatment }\end{array}$ & $\begin{array}{l}\text { Number of } \\
\text { patients without } \\
\text { treatment }\end{array}$ & $\begin{array}{l}\text { Number of } \\
\text { patients with } \\
\text { treatment }\end{array}$ & $\begin{array}{l}\text { Number of } \\
\text { patients without } \\
\text { treatment }\end{array}$ & & & \\
\hline \multirow{6}{*}{$\begin{array}{l}\text { Medical } \\
\text { treatment } \\
\text { (pediatric) }\end{array}$} & Heart failure & 5 & 17 & 8 & 14 & $86 \%$ & $100 \%$ & $63 \%$ \\
\hline & Antiarrhythmics & 1 & 21 & 1 & 21 & $100 \%$ & $100 \%$ & $100 \%$ \\
\hline & Antithrombotic & 14 & 8 & 15 & 7 & $86 \%$ & $86 \%$ & $87 \%$ \\
\hline & Systemic hypertension & 2 & 20 & 2 & 20 & $91 \%$ & $95 \%$ & $50 \%$ \\
\hline & $\begin{array}{l}\text { Pulmonary } \\
\text { hypertension }\end{array}$ & 3 & 19 & 3 & 19 & $100 \%$ & $100 \%$ & $100 \%$ \\
\hline & Immunomodulatory & 0 & 22 & 0 & 22 & $100 \%$ & $100 \%$ & - \\
\hline \multirow{2}{*}{$\begin{array}{l}\text { GUCH } \\
\text { information on } \\
\text { treatment }\end{array}$} & Pacemaker & 8 & 171 & 10 & 174 & $98 \%$ & $99 \%$ & $70 \%$ \\
\hline & $\begin{array}{l}\text { Medical cardiovascular } \\
\text { therapy }\end{array}$ & 70 & 110 & 81 & 103 & $91 \%$ & $97 \%$ & $84 \%$ \\
\hline \multirow{22}{*}{$\begin{array}{l}\text { Medical } \\
\text { treatment } \\
(\mathrm{GUCH})\end{array}$} & Sotalol & 3 & 80 & 3 & 80 & $100 \%$ & $100 \%$ & $100 \%$ \\
\hline & $\begin{array}{l}\text { Class I antiarrhythmic } \\
\text { agent }\end{array}$ & 1 & 82 & 1 & 82 & $100 \%$ & $100 \%$ & $100 \%$ \\
\hline & Amiodarone & 1 & 82 & 0 & 83 & $99 \%$ & $99 \%$ & - \\
\hline & Other antiarrhythmic & 1 & 82 & 2 & 81 & $99 \%$ & $100 \%$ & $50 \%$ \\
\hline & Beta blocker & 23 & 60 & 27 & 56 & $90 \%$ & $96 \%$ & $78 \%$ \\
\hline & Calcium channel blocker & 6 & 77 & 10 & 73 & $95 \%$ & $100 \%$ & $60 \%$ \\
\hline & Digitalis & 3 & 80 & 2 & 81 & $99 \%$ & $99 \%$ & $100 \%$ \\
\hline & Diuretics & 13 & 70 & 18 & 65 & $89 \%$ & $97 \%$ & $61 \%$ \\
\hline & Nitro-glycerine & 0 & 83 & 1 & 82 & $99 \%$ & $100 \%$ & $0 \%$ \\
\hline & $\mathrm{ACEl}^{\mathrm{a}}$ & 11 & 72 & 12 & 71 & $96 \%$ & $99 \%$ & $83 \%$ \\
\hline & $A R B^{b}$ & 17 & 66 & 19 & 64 & $95 \%$ & $98 \%$ & $84 \%$ \\
\hline & $\mathrm{ASA}^{\mathrm{C}}$ & 24 & 59 & 29 & 54 & $89 \%$ & $96 \%$ & $76 \%$ \\
\hline & $\begin{array}{l}\text { Thrombocyte inhibitor } \\
\text { other than ASA }\end{array}$ & 4 & 79 & 3 & 80 & $94 \%$ & $96 \%$ & $33 \%$ \\
\hline & Warfarin & 18 & 65 & 18 & 65 & $93 \%$ & $95 \%$ & $83 \%$ \\
\hline & $N O A C^{d}$ & 6 & 77 & 7 & 76 & $99 \%$ & $100 \%$ & $86 \%$ \\
\hline & $\begin{array}{l}\text { Other agent against } \\
\text { systemic hypertension }\end{array}$ & 0 & 83 & 2 & 81 & $98 \%$ & $100 \%$ & $0 \%$ \\
\hline & $\begin{array}{l}\text { Endothelin receptor } \\
\text { antagonist }\end{array}$ & 2 & 81 & 3 & 80 & $99 \%$ & $100 \%$ & $67 \%$ \\
\hline & Sildenafil & 1 & 82 & 1 & 82 & $100 \%$ & $100 \%$ & $100 \%$ \\
\hline & Prostacyclin analogue & 0 & 83 & 0 & 83 & $100 \%$ & $100 \%$ & - \\
\hline & $\begin{array}{l}\text { Other drugs against } \\
\text { pulmonary hypertension }\end{array}$ & 0 & 83 & 0 & 83 & $100 \%$ & $100 \%$ & - \\
\hline & $\begin{array}{l}\text { Drug against } \\
\text { hyperlipidaemia }\end{array}$ & 19 & 64 & 17 & 66 & $98 \%$ & $97 \%$ & $100 \%$ \\
\hline & Oxygen therapy & 0 & 83 & 0 & 83 & $100 \%$ & $100 \%$ & - \\
\hline
\end{tabular}

${ }^{\mathrm{a}} A C E$ angiotensin-converting-enzyme inhibitor, ${ }^{\mathrm{b}} A R B$ angiotensin II receptor blockers, ${ }^{\mathrm{C}} A S A$ acetylsalicylic acid, ${ }^{\mathrm{d}} \mathrm{NOAC}$ new oral type of anticoagulatia

process from pediatric cardiology to GUCH and the assessment of QoL in children with heart disease, as well as the risk of pulmonary hypertension in children and young adults who were born prematurely [3, 18]. Further research using SWEDCON, and by linkage to governmental and other disease specific quality registers, may evaluate preoperative risk factors for predicting intra- and postoperative adverse event and outcomes. Examples are studies of atrial septal defect (ASD) closure in small children as well as in elderly $[17,19]$. Thus, the valid data retrieved from SWEDCON is well suitable to be used in research studies. 
The links to government-administered national registries is one of the main strengths of the Swedish quality registers, including SWEDCON [20]. Low concordance between register data and medical journals was found in a study from Denmark, which was explained by diagnoses not being altered in the register after a patient had been referred to a specialized unit that changed the diagnosis [21]. In SWEDCON, mortality is either derived from user input - the basis for our analysis - or from monthly updates to official statistics, which are used in analytical reports from the register. The missing information on one death in our study may have been due to this monthly delay.

This study includes a large range of variables in pediatric and $\mathrm{GUCH}$ patients with five different cardiac diagnoses, which allows a sufficient sample size for testing the register. Differences in registration procedures were accounted for by including a variation in the size of hospital. All data in SWEDCON was validated according to medical records based on strict and predefined criteria in this study and performed by one observer (AB). This strengthens the study. However, this was a sample study at four hospitals affiliated to SWEDCON, so if a patient had changed hospitals, to a hospital not included in the study, we were unable to confirm their information in SWEDCON against the medical records of the new hospital. A few small hospitals in Sweden have not yet been affiliated to SWEDCON, which may influence advice on the best clinical practice based on research from the register. It is therefore important that a majority of centers, preferably all, that monitor children and adults with congenital heart disease are affiliated to SWEDCON.

Complete validation between data from all medical journals and SWEDCON would be difficult, time-consuming and expensive. In order to further validate SWEDCON, the research group plans to study the concordance between all patients in SWEDCON and the Swedish National Patient Register with regard to diagnosis and date of visit.

\section{Conclusion}

This validity study of SWEDCON found substantial agreement between information in the register and medical records. Data in SWEDCON can be considered reliable and can be used in research and health care improvements. However, improvements can be made to the register, especially concerning concordance in registration, through the use of similar diagnostic codes for surgeries and interventions in both medical records and SWEDCON.

\section{Abbreviations}

EPCC: European pediatric cardiac coding; GUCH: Grown Up Congenital Heart disease; KVÅ: "Swedish classification of care measures"; QoL: Quality of life; SWEDCON: SWEDish registry of CONgenital heart disease

\section{Acknowledgements}

We thank the SWEDCON register and its steering committee for sharing data and the Uppsala Clinical Research Centre (UCR) for help with the randomizing and selection of data. We also thank all the doctors and nurses who work with patients with congenital heart defects in Sweden, who contribute data and make this register possible.

Funding

This paper has received no funding.

Availability of data and materials

The datasets used and/or analyzed during the current study are available from the corresponding author on reasonable request.

\section{Authors' contributions}

EN had the primary responsibility for study, protocol development, patient enrollment, outcome assessment, preliminary data analysis and writing the manuscript. GB and UT participated in the analytical framework for the study and contributed to the writing of the manuscript. $A B$ participated in the analytical framework of the study, was primarily responsible for collecting data from medical records and the registry, was primarily responsible for data analyses and contributed to writing the manuscript.

All authors read and approved the final manuscript.

\section{Authors' information}

At the time of the study, AB was a medical student at the Department of Clinical Science, Pediatrics, Umeå University, Umeå, Sweden.

$\mathrm{GB}, \mathrm{PhD}$, associate professor and senior consultant in pediatrics and pediatric cardiology at the Department of Pediatric Cardiology, University Hospital, Lund, Sweden.

UT, PhD, associate professor and senior consultant in cardiology and GUCH at the Department of Cardiology, University Hospital, Lund, Sweden.

$\mathrm{EN}, \mathrm{PhD}$, senior lecturer and a senior consultant in pediatrics and pediatric cardiology at Östersund County Hospital and the Department of Clinical

Science, Pediatrics, Umeå University, Umeå, Sweden.

\section{Ethics approval and consent to participate}

The study received ethical approval from The Regional Ethical Board at Umeå University, EPN Dnr: 2016/210-31. All patients have agreed to participate in SWEDCON and in research based on the register.

Consent for publication

Not applicable.

\section{Competing interests}

UT (GUCH) and GB (pediatric) are registry-holders of SWEDCON. AB and EN declare that they have no competing interests.

\section{Publisher's Note}

Springer Nature remains neutral with regard to jurisdictional claims in published maps and institutional affiliations.

\section{Author details}

${ }^{1}$ Department of Clinical Science, Pediatrics, Umeå University, Umeå, Sweden. ${ }^{2}$ Department of Pediatric Cardiology, University Hospital, Lund, Sweden. ${ }^{3}$ Department of Cardiology, University Hospital, Lund, Sweden. ${ }^{4}$ Unit of Research, Education and Development, Östersund Hospital, 83183 Östersund, Sweden.

Received: 6 October 2017 Accepted: 6 December 2017

/ Published online: 20 December 2017

\section{References}

1. Marelli AJ, lonescu-lttu R, Mackie AS, Guo L, Dendukuri N, Kaouache M. Lifetime prevalence of congenital heart disease in the general population from 2000 to 2010. Circulation. 2014;130(9):749-56.

2. Marelli AJ, Mackie AS, lonescu-Ittu R, Rahme E, Pilote L. Congenital heart disease in the general population: changing prevalence and age distribution. Circulation. 2007;115(2):163-72.

3. SWEDCON. SWEDCON annual report. http://www.ucr.uu.se/swedcon/ arsrapporter; 2015 
4. Analysis of quality register cover rate. Nationella kvalitetsregisters täckningsgrad. http://www.vardanalys.se The Swedish Agency for Health and Care Services Analysis.(in swedish). Myndigheten för vårdanalys; 2014.

5. Coding Committee of the Association for European Paediatric C. The European Paediatric Cardiac Code: the first revision. Cardiol Young. 2002;12 Suppl 2:1-211.

6. World Health Organization International Statistical Classifications of Diseases and Related Health Problems 10th Revision. http://www.who.int/ classifications/icd/en/.

7. National board of Health and Wellfare. Classification of operations and interventions. Socialstyrelsen. Klassifikation av vårdåtgärder.(in swedish). http://www.socialstyrelsen.se/klassificeringochkoder.

8. Hagman E, Arani PI, Fischer M, Danielsson P, Marcinkiewicz K, Petriczko E, et al. Blood sugar levels are higher in obese young children in Sweden than in Poland. Acta Paediatr. 2014;103(11):1174-8.

9. Rodby-Bousquet E, Agustsson A, Jonsdottir G, Czuba T, Johansson AC, Hagglund $G$. Interrater reliability and construct validity of the posture and postural ability scale in adults with cerebral palsy in supine, prone, sitting and standing positions. Clin Rehabil. 2014;28(1):82-90.

10. Friling E, Lundstrom M, Stenevi U, Montan P. Six-year incidence of endophthalmitis after cataract surgery: Swedish national study. J Cataract Refract Surg. 2013;39(1):15-21.

11. Baumgartner $\mathrm{H}$. What news in the 2010 European Society of Cardiology (ESC) guidelines for the management of grown-up congenital heart disease? J Cardiovasc Med (Hagerstown). 2013;14(2):100-3.

12. Baumgartner H, Bonhoeffer P, De Groot NM, de Haan F, Deanfield JE, Galie $\mathrm{N}$, et al. ESC guidelines for the management of grown-up congenital heart disease (new version 2010). Eur Heart J. 2010;31(23):2915-57.

13. Berglund E, Johansson B, Dellborg M, Sorensson P, Christersson C, Nielsen $\mathrm{NE}$, et al. High incidence of infective endocarditis in adults with congenital ventricular septal defect. Heart. 2016;102:1835-1839.

14. Sandberg C, Engstrom KG, Dellborg M, Thilen U, Wadell K, Johansson B. The level of physical exercise is associated with self-reported health status (EQ-5D) in adults with congenital heart disease. Eur J Prev Cardiol. 2015;22(2):240-8.

15. Sandberg C, Rinnstrom D, Dellborg M, Thilen U, Sorensson P, Nielsen NE, et al. Height, weight and body mass index in adults with congenital heart disease. Int J Cardiol. 2015:187:219-26.

16. Sandberg C, Thilen U, Wadell K, Johansson B. Adults with complex congenital heart disease have impaired skeletal muscle function and reduced confidence in performing exercise training. Eur J Prev Cardiol. 2015;22(12):1523-30.

17. Thilen M, Christersson C, Dellborg M, Mattsson E, Trzebiatowska-Krzynska A, Thilen U. Catheter closure of atrial septal defect in the elderly ( $>/=65$ years). A worthwhile procedure. Int J Cardiol. 2016;218:25-30.

18. Naumburg E, Soderstrom L, Huber D, Axelsson I. Risk factors for pulmonary arterial hypertension in children and young adults. Pediatr Pulmonol. 201752;636-641. doi:10.1002/ppul.23633.

19. Tanghoj G, Odermarsky M, Naumburg E, Liuba P. Early complications after percutaneous closure of atrial septal defect in infants with procedural weight less than $15 \mathrm{~kg}$. Pediatr Cardiol. 2017:38(2):255-263

20. Emilsson L, Lindahl B, Koster M, Lambe M, Ludvigsson JF. Review of 103 Swedish healthcare quality registries. J Intern Med. 2015;277(1):94-136

21. Lasota AN, Overvad K, Eriksen HH, Tjonneland A, Schmidt EB, Gronholdt MM. Validity of peripheral arterial disease diagnoses in the Danish National Patient Registry. Eur J Vasc Endovasc Surg. 2017;53:679-85.

\section{Submit your next manuscript to BioMed Central and we will help you at every step:}

- We accept pre-submission inquiries

- Our selector tool helps you to find the most relevant journal

- We provide round the clock customer support

- Convenient online submission

- Thorough peer review

- Inclusion in PubMed and all major indexing services

- Maximum visibility for your research

Submit your manuscript at www.biomedcentral.com/submit
Biomed Central 